\title{
AN ANALYTIC DISCUSSION ON ARCHITECTURE AS AN ART
}

\author{
Adewale Segun Alabi ${ }^{\star 凶}$ and Oluwadamilola Ajoke Alabi \\ Department of Architecture, Bells University of Technology, KM 8, Idiroko Road, Ota, Ogun State, Nigeria
}

\author{
Research Article \\ PII: S238315532000001-9 \\ Received: 22 Apr. 2020 \\ Revised: 30 May. 2020 \\ Published: 15 Jun. 2020 \\ Corresponding author: \\ E-mail: segunwale@gmail.com
}

\begin{abstract}
Architecture has been characterized to be a form of art by different scholars in the design field. Questions as to "whether architecture is always, sometimes of never an art form?', and 'if architecture is an art form, what makes it distinct from other art forms?' have arisen. These questions are answered in this paper through metaphysical discussion underpinned by analytic philosophy of architecture. The argument put forward in this study provides a platform from which students of architecture and practicing architects can grasp the knowledge of the fundamental need for architecture to perform as an art and be much more than a mere aesthetic message. Thus, the study reveals architecture to be an art form which is distinct from other art forms because it goes beyond art to reveal itself as design which provides a particular functional requirement that shows responsibility for its existence.
\end{abstract}

KEYWORDS: Architecture, Art, Buildings, Analytic Philosophy

\section{INTRODUCTION}

For centuries, there has been debate as to whether architecture 'always, only sometimes or never is an art form' [1]. Many scholars termed architectural works as being generated from the abstract to the real. While in the artistic world, works are created from the real to the abstract [2-6]. This gives a clear understanding of the formality of architectural works. Architecture as a profession contends with various disciplines and is guided by different principles within the field of arts, sciences, economics and many other diverse disciplines. It has always been considered an art, because it requires imagination and creativity. However, it goes beyond that. It must extend to the end users of the building, their experience, feeling, emotion, satisfaction etc. This broad application sometimes gives architecture an edge over the mere art form which can sometimes be understood and interpreted by only the artist.

\section{Architecture as an Art - the Argument}

Architecture is both an art and science at the same time [7, 8]. The art of a building and the science of that same building must exist before it can be referred to as architecture [9]. However, architecture is influenced by the philosophical stand of the designer and therefore the translation of thoughts into a form designed to function as a space for housing a functional space, at the same time an expressive activity [10]. The structure loses value as an architectural form and becomes a purely artistic form if the factor of functionality is ignored. Likewise, if the sense of expression is ruled out in the creation of a building, it immediately loses its architectural quality and remains a mere building. This thought is emphasised by Pevsner [11] who stated that building designed with aesthetic appeal is architecture.

In a bid to understand the genealogy of these ideas, there is need to appreciate what constitutes architectural form (elements). Architectural forms can be combined in various elements, just like artistic elements, which also are mostly related to architectural elements such as basic elements, sensory elements, formal elements, technical elements, and expressive elements [12]. Architects design buildings using a creative process by which they manipulate different elements to create integrated and pleasing statement which must satisfy basic attributes, which according to Vitruvius are three guiding principles connoting - firmitas (strength), utilitas (functionality and venustas (aesthetics). In the light of this, architecture can be perceived to always be an art form characterised by other external attributes. As posited by Hillman [13], in his article 'How to Make Architecture, Not Art', art is defined as a form of self-expression with absolutely no responsibility to anyone or anything while architecture is connoted to mean a piece of art which must be responsible to people in its different contexts. Therefore, in Architect Richard Meir's words, "Architecture is the greatest of arts". 


\section{DISCUSSION}

\section{Architecture as more than an art form}

The major frustrations most architects experience professionally is the difficulty in making analytic arguments in favour of aesthetic decisions in design [14]. Architecture, generally speaking, consists of arts, sciences and other diverse disciplines. In fulfilling Vitruvius' triad of firmitas, utilitas and venustas, architecture encompasses the utilitarian concept, performs certain functions and accommodates human needs, behaviours and ergonomics through which it is holistically defined. However, in dealing with artistic tendencies, architects must be able to distinguish venustas from one of Vitruvius triad principle of which the anchor strength is in beauty, aesthetics etc. On this premise, we can base our argument of differentiating art form in architecture from other art forms such as sculpture, painting and music.

Architecture comes about through a systematic process in response to a need while other forms of art are manifest without a responsibility to a need. Art is a creative expression that transcends the functional requirements of its existence in any form one chooses to manifest it. An artist is someone who expresses his/her thoughts irrespective of what others like or dislike. It is an extension of the artist's mind and has nothing to do with the constraints. Architecture on the other hand is artistic products derived from the process of synthesizing information in construction, engineering, human behaviour and needs, and formal aesthetic order for the purpose of responding to a particular problem involving human use and habitation which contributes to the cultural capital of the society that benefits from such a product.

Architecture is a science, which is a subset of art, which involves solving problems with an artistic approach, considering constraints and coming out with the best possible optimized solution. When an intended piece of architecture is forced to be an art, it likely ends up being a sculptor and loses the enabling characteristics of architecture. However, there are occasions of the craft of architecture becoming art: where the intention was not to make art but where the craft was so exquisite that the result is mystical appellation. An example is the Basilica De la Sagrada Familia designed by Antonio Gaudi (1852-1926) [15] see figure 1.

Art now bears no responsibility for its actions. It is subversive. Art is not a service, but an opinion [16]. Architecture has a social responsibility; it must appeal to the client, must follow by-laws and meet deadlines and budgets. Architecture is at its core, part of a service [17]. Therefore, while architects resolve pre-existing problems into something with harmony, artists create the "problem" and then resolve it into something with harmony [14].

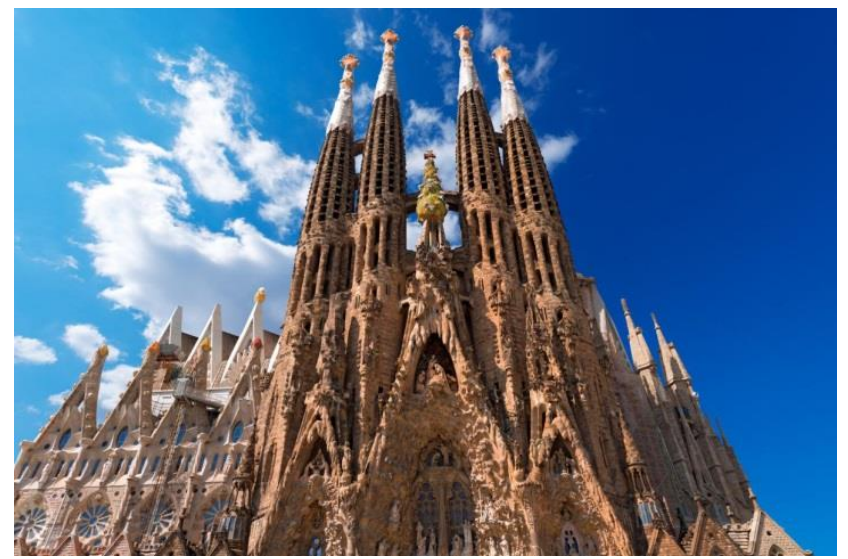

Figure 1. Basilica de la Sagrada Familia architecture as a prominent work of art (Source: www.triphobo.com)

The excellence of a visible work of art such as a sculpture is dependent on factors of balance and expressiveness of the forms employed' [14]. However, balance and expressiveness of form in conjunction with functionalism identifies a work of architecture. Therefore, a building designed primarily to be a work of art denies that building from being regarded as architecture in the pure sense of the word.

Architecture cannot be moved about and remains unchanged unlike other forms of art. Books, music and pictorial art works can be created in one place and moved or reproduced in another place without experiencing any change in aesthetic character. Examples are books written, translated into various languages, reproduced and distributed all over the world yet carrying the same message (such as the Holy Bible) or music playing in Nigeria and getting a response from the audience which is exactly the same as those listening to the same artist in Belgium and yet still inspiring yet the same reaction from an audience in South Africa listening to a reproduction of the same music by another artist. However, an attempt at moving a work of architecture from its original place to another or creating a replica or prototype changes the characteristic of the moved or replicated building from being a work of architecture because the action would have made it lose one or two of the three functions making it architecture. This is because architecture has a highly localized quality $[14,18]$. 
The site of the architectural work greatly influences its features in terms of the terrain, orientation, climatic conditions, cultural setting, materials etc. Hence, when architecture is relocated, it is placed within an alien site which was never considered during the creation of the original building causing it to lose its value as a work of architecture.

Most 'drastic' changes in the aesthetics of architecture such as the movements in history of architecture are borne not because of change in taste but more because of the discovery of new technology [14]. For instance, the discovery of the use of concrete to achieve various forms tending towards organic architecture such as buildings manually designed by Frank Lloyd Wright evolving into more complex structures designed with the use of advanced computer aided design software by Zaha Hadid. Meanwhile changes to other arts are primarily because of changing attitude to which art gives. For illustration, the black art movement came as a need to transform the way African Americans were portrayed in the arts and literature [19].

Architecture is different from many other art forms as it cannot be ignored by the public while other art forms can be. The public can decide not to be entertained by art works such as literature, music or painting, which do not appeal. However, due to the unmistakable physical presence of a work of architecture, the public is compelled to experience it, making architecture a public object. The expressive character of other arts is acquired from the personal way they are approached while the expressive character of architecture is acquired from an objective representation of manner and style. Thus, architecture speaks publicly and without intimacy to the observer but generates feelings that may be very strong emotions mostly tied to wonderment of the creator. Similarly, strong emotions can be generated by other art forms but expressions of most of these other art forms are quite private, generating a connect not with the creator but with the art [14].

\section{CONCLUSION}

Architecture by definition is the built environment that results from a scientifically grounded collaboration between different service-base parties. Built environment can both be interpreted subjectively and objectively by the viewer, but must adhere to rationalised processes concerning design, construction, engineering, and peer review, if it were to be realised in the real world. Architecture goes beyond art; it is a design process. If it ceases to be design, then it no longer provides a particular functional requirement. Art in architecture is the art in craft, the ability of the architect to manipulate light and materials to define space is a good equivalence. This is essentially not different from a master craftsman making baskets, pottery, furniture, etc. as craftsmen strive to impress our mentors and peers.

\section{DECLARATIONS}

\section{Acknowledgements}

The authors would like to thank Zanzan Uji, Professor at University of Jos, Plateau State for his invaluable support in the development of this research paper.

\section{Authors' Contributions}

Alabi A. S. is the lead author of the manuscript. He provided the background, the body of the work and analytical interpretation of the work. Alabi O. A. developed the abstract and worked on the conclusion. All the authors directly participated in analysis of this study, and have read and approved the final version submitted.

\section{Competing interests}

The authors declare that they have no competing interests.

\section{REFERENCES}

[1] Moore CW (1965). Architecture-Art and Science. Journal of Architectural Education. 19(4):53-6. DOI: https://doi.org/10.1080/00472239.1965.11102220, Google Scholar

[2] Evans R (2000). The projective cast: architecture and its three geometries. MIT press. Google Scholar

[3] Holl, S. (2013). Critics Page: Brooklyn Rail. Retrieved from brooklynrail.org: www.brooklynrail.org/2013/o9/criticspage/what-isarchitecture-art

[4] Glanville R. (2007). Cybernetics and design. Special double issue of Kybernetes, 36 (9/10); Jones, PH (2014). Systemic Design Principles for Complex Social Systems. Social Systems and Design. 2007:91128. Google Scholar

[5] Sweeting B (2011). Conversing with drawings and buildings: from abstract to actual in architecture. Kybernetes: The International Journal of Systems \& Cybernetics. 40(7-8):1159-65. Google Scholar, DOI: https://doi.org/10.1108/03684921111160386

[6] Evans R and Difford R (1997). Middleton R. Translations from drawing to building and other 
essays. London: Architectural Association; 1997 Jun. Google Scholar

[7] Boroson K (2016). Kenneth Boroson Architects. Retrieved January 15, 2020, from Articles from Kenneth Boroson Architects: www.kbarch.com

[8] Mizia M (2014). Architecture as an Art of Understanding. The Polish Review. 59(4):81-92. DOI:https://doi.org/10.5406/polishreview.59.4.00 81, Google Scholar, JSTOR

[9] Mitrovic B (2015). Visuality, intentionality and architecture. Review of: John Searle: Seeing things as they are, (Oxford: Oxford University Press, 2015). Journal of Art Historiography. (14):1-17. Google Scholar, ProQuest

[10] JAAC (2011). Contributors. The Journal of Aesthetics and Art Criticism, 69(1), 143-145. Retrieved January 15, 2020, from www.jstor.org/stable/42635845

[11] Pevsner N (1943). An Outline of European Architecture. Pelican. Google Scholar, Direct Link

[12] Unwin S (2009). Analysing Architecture. London: Routledge. Google Scholar

[13] Hillman, D. (2013). How to Make Architecture, Not Art. Retrieved June 27, 2016, from Arch Daily:
https://www.quora.com/Why-is-architectureconsidered-as-an-art

[14] Scruton R (1979). The Aesthetics of Architecture. Princeton: Princeton University Press. Google Scholar

[15] Biography.com Editors (2014) Antoni Gaudí Biography. (1852-1926). A\&E Television Networks. https://www.biography.com/artist/antoni-gaudi,

[16] Nieters J (2019). Philosophy Now. (Cambridge University Press) Retrieved October 13, 2019, from https://philosophynow.org/issues/108/what is_art and or what is beauty

[17] Oluwatayo AA (2009). A Critical Study of the Practice Characteristics of Architectural Firms in Nigeria (Doctoral dissertation, Ota: Covenant University, Unpublished $\mathrm{PhD}$ thesis.). Google Scholar

[18] Nay E (2014). Alternatives Journal. Retrieved from Alternatives Journal Web Site: http://www.alternativesjournal.ca/community/blogs Lmade-canada/sustainable-architecture-localisedarchitecture

[19] Academy of American (2014). Academy of American Poets. Retrieved from Academy of American Poets. Website: http://www.poets.org/text/brief-guide. 